\title{
Early Iron Age
}

\author{
Eva Bergström
}

\begin{abstract}
In this survey the Early Iron Age includes the Pre-Roman Iron Age, the Roman Iron Age and the Migration Period. Results and experiences from excavations and field inventories are summed up. The ongoing debate concerning general problems is mirrored, such as change in settlement pattern, in social organization, in handicraft and trade as well as in religion. The survey should not be considered as comprehensive, why several interesting works must be left unconsidered.
\end{abstract}

Eva Bergström, Department of Archaeology, Stockholm University, S-106 91 Stockholm, Sweden.

\section{SETTLEMENTS AND HOUSE FOUNDATIONS}

The conditions for settlement studies have changed with the large-scale rescue excavations from the 1980s and on. It is now possible to start from known, dated settlements, in contrast with earlier conditions when you had to work from the location of cemeteries. However, that the methods used in the field inventories for the Economic Map of Sweden are quite insufficient for finding Iron Age settlements, is evident from the experiences made during the 1980s. More settlements have been documented than was earlier thought possible, but as a consequence of investigations of known, registered ancient monuments, most of which are graves. The importance of test excavations should not be overestimated concerning the localization of settlements. As methods of retrieval, unconventional ones might be developed such as the documentation of water holes or vegetation. Today there are even better conditions for discussing the duration of settlements and their patterns of movement (Hedman 1987).

Sites with heaps of fire-cracked stones, earlier looked upon as indicators of Bronze Age settlements, might also indicate settlements from the earliest Iron Age. In the province of Södermanland settlements with heaps of fire-cracked stones have been used also during this time. The continuity has also reference to the construction of houses. During both periods the roof was supported by upright poles and the walls consisted of wattle and daub. A sill of stone has been found, which supported a building from the Early Iron Age (Wigren 1987).

During a period of about twenty years up to the middle of the 1980 s about thirty settlements from the Late Bronze Age and Early Iron Age have been excavated in the province of Östergötland, most of them found through test excavations. Twelve of them were dated to the Roman Iron Age and Migration Period. Some were used during the Late Bronze Age, for example, the Tallboda site in Rystad parish. Graves and settlement remains were quite intermingled. The threeaisled houses of the Early Iron Age were oriented east-west and were somewhat longer than the houses of the Late Bronze Age. Slag and fragments of moulds indicate metallurgy, a very frequent trait at settlement sites in the region from this time. If the locations of settlements are simulated from the locations of cemeteries from the Pre-Roman Iron Age, a fairly even distribution appears with a mean distance of about 


\section{$3 \mathrm{~km}$ (Fernholm 1987).}

During the 1980 s several rescue excavations were carried out in the province of Uppland. Heaps of fire-cracked stones here may also indicate settlements from the Early Iron Age, and there are also indications of metallurgy such as slag and moulds. Surprisingly often the Early Iron Age settlements are situated on clayey soils, for example, Prästgårdshagen in Björklinge parish. This type of location might indicate an increased need of fodder supply, perhaps at newly established settlements. At Målsta, Bälinge parish, fragments of clay from daubed walls have been found covered with a white slip, perhaps fragments from a whitecoloured house. So-called striated ceramics have also been found at the settlements of Uppland, indicating contacts with southwestern Finland and Estonia (HjärthnerHoldar \& Söderberg 1987).

At Tibble, Litslena parish, a site has been excavated containing heaps of firecracked stones, house-foundations and a cemetery, indicating settlement continuity from the Late Bronze Age into the Early Iron Age. Settlements have probably been established in regions that became usable thanks to land elevation. The expanding PreRoman settlements were probably evenly distributed in the landscape, but were clustered during the Late Roman Iron Age. Some houses had a sill of stone and were probably built of timber. Part of a long-house from the Late Roman Iron Age was evidently used as a cowshed (Andersson \& HjärthnerHoldar 1989).

A Pre-Roman cellar was found below a house with a sill. The house was probably built in cross-timber, a surprisingly early date for this building technique (Andersson 1989). At Tibble a richly furnished chamber grave from the Late Roman Iron Age had been excavated earlier. With respect to the very early cross-timber technique, the region might have been an innovative one during the Late Roman Iron Age (Andersson \&
Hjärthner-Holdar 1989).

In the three-aisled houses usual during the Early Iron Age in the Mälar region, the central aisle seems to be narrower over time, just as it is in Jutland. The houses were probably divided according to different functions, at least as dwelling and cowshed (Göthberg 1989).

A Pre-Roman long-house was excavated at Gothenburg and seeds of millet were found (Lundh 1988). During several years a Pre-Roman cemetery and a nearby settlement were investigated by the Department of Archaeology at the University of Gothenburg. Among other things, ceramics and seeds of flax were found at the settlement site (Arwill-Nordbladh \& Jankavs 1988).

Beetling crags have sometimes been used as a shelter for temporary settlement on the Swedish west coast. Such a site has been excavated at the foot of a $50 \mathrm{~m}$ high, upright cliff in Norum parish in the province of Bohuslän. Judging from bone fragments of wild as well as domesticated animals, the site was used for hunting expeditions from the Late Bronze Age up to the Viking Age (Ängeby 1989).

A lot of clay fragments from a house with walls of wattle and daub have been found in Forsa parish, in the province of Hälsingland. Impressions in the clay show that the wickers came from tiny spruce and pine, and the wall poles were made of pinewood. Only the inside of the walls seems to have been smoothed with clay (Melander 1989).

\section{REGIONAL SURVEYS}

The scientific discussion concerning middle Norrland of the Early Iron Age has been more differentiated concerning old problems, such as the kind and extent of settlement, the origins of settlements, and their contacts with other regions. Some rescue excavations have been carried out by the Department of Archaeology at the University of Umeå.

There are good reasons for regarding 
middle Norrland as a cultural province of its own already in the Late Bronze Age, which Evert Baudou has emphasized in several publications. The Pre-Roman Iron Age is, however, still a mysterious phase. Results from pollen analysis indicate fairly permanent settlements, and some types of stone-settings might emanate from this time. Pits filled with ashes and bones from domesticated animals, found below later barrows, might indicate settlements. During the PreRoman Iron Age cemeteries were established at the lakes in the inner parts of middle Norrland, perhaps as a result of influences from the Mälar region or from eastern Norway (Liedgren 1987).

Liedgren uses the parish of Forsa as a model region for analysing settlement patterns during the Roman Iron Age and Migration Period. From the spatial distribution of graves and settlements he concludes that about ten primary settlements were established during the Early Roman Iron Age. Secondary settlements were then established, forming a dense settlement pattern during the Migration Period. The secondary settlements used the same resources as the primary ones but were smaller. In the late Migration Period several farms were burnt down, perhaps in connection with regional or inter-regional conflicts (Liedgren 1989).

Monumental grave-monuments with richly furnished graves, together with the construction of several hill-forts, may indicate an accelerating crisis in the Late Roman Iron Age and Migration Period. Settlements in middle Norrland might have been organized in a manner corresponding to the "folkland" principle known from historical time. The supposed prehistoric "folklands" had probably the same kind of organization between them. Social stratification is probable and an élite, exemplified by the man in the rich grave from Högom, was integrated into a vast network of contacts with both the Continent and, for example, Norway. In monumentality and position in the land- scape the Högom mounds are very remindful of the famous cluster of mounds at Bertnem in Norway and that at Old Uppsala. Below Mound 4 at Högom a house foundation was found, the front part of which was especially emphasized by a special construction known also from a house at Gene in the province of Angermanland. Below Mound 3 at Högom a smaller house was found, used perhaps for special meetings. Because of this, Högom can be interpreted as a primary residential unit for a "folkland", which in one way or another outmanoeuvred the others in middle Norrland in the late Migration Period. Högom might also have been important for the distribution of iron ingots in a long-distance trade system (Ramqvist 1987).

In the province of Jämtland iron production expanded from the fourth up to the seventh century but especially during the fifth century. At sites specializing in iron production, spade-shaped ingots were produced to an extent large enough for supplying markets in Tröndelag, on the Bothnian coast, and in the Mälar region. Needs and distribution may also depend on warfare and other conflicts on the Continent. Probably there were in Jämtland local bases supporting an expanding iron production. For instance, the hillfort of Mjälleborgen on the island of Frösön was built at the latest in the fifth century. Social differences are evident from the graves in Jämtland. There are rich graves in mounds as well as poor burials in graves, filled with iron slag. Magnusson regards these centuries of intense, specialized iron production as an example of a phase in a cyclic, economic trajectory (Magnusson 1987).

With a foothold in Marxist theory, Thomas B. Larsson emphasizes that the relation between production and social reproduction is a key concept in studying economic change. He treats change from the Late Bronze Age into the Pre-Roman Iron Age in the province of Östergötland from this 
point of view. He regards the heaps of firecracked stones as remains from a settlement pattern where the settlements were situated according to resources and social circumstances. The Bronze Age cairns are located at a distance from these settlements. The votive deposits are situated at a distance from both cairns and settlements. Figure-rich rock-carvings are situated in the periphery of settlement regions. In type, location, and function, these different remains mirror different functions in the relation production/ social reproduction and within a society interpreted as a segmentary tribe. The clusters of cairns had a common meaning for several settlements, and the rock-carving sites had a special, symbolic meaning for still greater numbers of people.

In the Pre-Roman Iron Age this pattern totally changed. A small-scale society appears, characterized by small, independent settlement units. Contrary to the pastoral economy in the Bronze Age, cultivation became important. The settlements, defined by a network of stone fences, were probably "owned" by an extended family. Each settlement unit had a cemetery of its own, situated close to the fields and pastures. The social organization had changed from vast social units to independent families; from a collectivistic society to an individualistic one (Larsson 1989).

Hans Lundmark discusses the hierarchization process of segmentary societies, also applicable to the changes during the Late Bronze Age and Early Iron Age. Foremost by trend-surface-method, he analyses the Ancient Monument Register for the Economic Map of Sweden. Provided that external circumstances are alike, that damages from recent agriculture don't interfere with the distributional pattern of ancient monuments, and that the chronology is correct, the ancient monuments which are remains from a segmentary society should make evenly distributed clusters of analogous kind. Remains from a stratified society should show centers, that is, evenly distributed high-ranked units surrounded by units of a lower rank. Around complexes of highranked and low-ranked units, buffer-zones should be discerned. If erected stones, a kind of grave monument, symbolize settlements from the Early Iron Age, a pattern of evenly distributed units is discerned in south and middle Sweden. In the Roman Iron Age, settlements seem to be situated in extensive clusters in areas corresponding to provinces. Within these clusters there is a faint tendency toward minor clusterings at a regional level, perhaps an indication of increasing hierarchization. In western Sweden, for example, this process may depend on iron production where uneven access to resources and the need to control the distribution initiates competition and hierarchization. The more even distribution of stone circles from the Late Roman Iron Age may indicate that this process was hampered (Lundmark 1989).

Björn Winberg comments on the settlement studies carried out by human geographers on stone fence-systems in the province of Östergötland, among others by Widgren. Winberg emphazises the immense number of fences recently documented during the field-surveys for the Economic Map. The systems of stone fences seem, however, to be so accidentally preserved that they can't be used as the only source for settlement studies. The pattern must be complemented with graves. Winberg analyses the combination of grave-types from some parishes in order to find chronological groups. Simple types such as mounds and round stone-settings constitute one group from the Late Iron Age. Infilled stone-settings, square ones, stone-settings with mid-construction as well as erected stones constitute another group, from the Early Iron Age. Stone circles appear in both groups. Cemeteries with varying types of monuments seem to represent Early Iron Age settlements, perhaps abandoned later on (Winberg 1986). 
With the aid of the Register of Ancient Monuments, Lennart Klang also treats settlement problems but with reference to the north-eastern part of the province of Småland. He proposes that settlements were established in several phases during the Iron Age. In the first phase the inland regions became attractive for sedentary settlements dispersed in the landscape. Because both weapon-graves and remains of iron production are known, the Roman Iron Age probably was an expansive phase. Later on settlements were relocated to valleys with good pre-requisites for fodder collecting, important if the fields were manured (Klang 1986).

In Volume I of Ölands järnåldersgravfält all the known graves and cemeteries in seven parishes on the island are published. A sharp difference appears between the western coast and the eastern. Westwards simple, round stone-settings are most frequent, and in this region Köpingsvik develops into a centre during the Late Iron Age. In the east low stone-settings from the Early Iron Age are frequent.

When analysing graves from two parishes, situated within a $5 \mathrm{~km}$ distance from the sacrificial bog of Skedemosse, Beskow Sjöberg finds that inhumation was firmly, but not totally, accepted during the Early Roman Iron Age, when social stratification is indicated by the grave-finds. The number of grave-gifts diminishes in the Late Roman Iron Age, when the continuity of the big cemeteries ceases. The solitarily situated graves from the Late Roman Iron Age and Migration Period are sometimes difficult to identify, which is why these periods are often said to be characterised by diminishing population and crisis. Estimated from the number of house foundations, the settlement was dense also when the cemetery tradition changed, and votive offerings were made in the bog of Skedemosse also during the Migration Period (Beskow Sjöberg 1987).

\section{HILLFORTS}

There is an evident ambition to interpret hillforts in a socio-economic context. A big hillfort was recently discovered by amateurs in Vist parish, Östergötland. From test excavations heavy, sometimes double, stone walls were documented and the hillfort evidently had several entrances. Datable artefacts were not found, but there are complexes of graves and stone fences nearby, which may date the hillfort to the Early Iron Age (Tagesson 1990).

Michael Olausson compares three, earlier investigated hillforts: Darsgärde in Uppland, Skovsta skans in Västmanland, and Gullborg in Östergötland. All of them have cultural debris, they are fairly small, they are situated close to arable soils, and they can be dated to about the fourth-sixth centuries. At Darsgärde several house foundations were found, usable for storage; at Skovsta skans among other things a sword-pearl and a bone spoon were found; and at Gullborg they had produced textiles. Olausson tests the hypothesis that hillforts seem to have been constructed when weapon-graves became frequent in eastern middle Sweden, and because they were used contemporaneously with chamber graves and big mounds, there is reason to interpret the function of hillforts as expressing an establishing élite. Spatial relationships to high-status graves are, however, not evident, which is why the hillforts may signal centres of lower rank. Hillforts were probably not used much later on when the grave-monuments became more standardized and the farming system changed, that is, in the late Migration Period (Olausson 1987).

The island of Öland was very densely settled in the Roman Iron Age and Migration Period, but there were differences between the settlements concerning access to arable soils. Because of this, dependence among settlements might have increased. The circular hillforts of the island should be considered in this connection. 
The house foundations of the hillfort of Eketorp, which are dated to its phases I and II, show a change from non-permanent settlement perhaps dependent on stockbreeding (phase I) to permanent settlement with independent households at the same time as one single house-group might be of higher rank than the others. Thereafter almost all the buildings were used as livinghouses and the independence disappeared. Then, all the living-houses were destroyed and only a small-scale use of the ruins was left (phase III). These changes should be related to an economic restructuring of the island. The early, expanding stock-breeding aiming at trade with the Continent was balanced against the necessity of satisfying the social needs of the population. The crisis of Öland in the Migration Period seems to be of an economic kind. The solidi coins found at the island suggest that direct contacts with the Continent changed to stagnation, in pace with the breakdown of the Continental urban life-style. Because the economy of the island was dependent on outer, large-scale economic systems, the crisis was matched with internal change into intensified agriculture and, to a certain extent, re-arrangement of settlements (Herschend 1988).

\section{GRAVES AND RELIGION}

Late Bronze Age and Pre-Roman Iron Age graves at Dragby in the province of Uppland have been analysed with mathematical methods in order to study signals of social structure and its change over time. The types of graves as well as the grave-gifts are looked upon as expressions of social attention, an aspect and expression of status. Contrary to the symbolic system used in the Late Bronze Age, such signals are very faint in the eraliest Iron Age when a new kind of society came into being (Ulfhielm 1988).

Anna-Lena Gerdin has discussed finds of drinking-cups of glass from Roman Iron Age graves on the island of Gotland. She looks at the grave-finds from two aspects: the deceased's need of drinking-cups in "the other world" and the descendant's need to drink "memorial toasts" (Gerdin 1989).

The vast amount of Migration Period graves in the Mälar Valley region, excavated from the 1960s up to the 1980s, have been analysed by Agneta Bennett with regard to their outer visible form, the grave-arrangements and the grave-gifts. She suggests that the outer, visible form and the inner, invisible traits express a symbolic language. There are differences in both external and internal grave-types. The external covariates with the sex of the buried person, but very little with its age. Men are mostly buried in inhumation graves; both men and women can be cremated, however. The attention paid to the visible traits of the graves covariates with rank as expressed in gravegoods. Weapons and rank-indicating artefacts are very few, and both male and female combinations of artefacts can be discerned. The volume of animal bones is greater in male graves, where also bear-claws appear. The stone-settings at female graves are more delicately constructed, while stonesettings at male graves have varying dimensions.

The varying symbolic language is simplified and uniform during the Migration Period, and the cremation graves become predominant. However, both the varying and the simplified symbolic language are used contemporaneously for a time; thereafter the simplified symbolic language dominates. This change may express a change in religion. An increase in monumentality as well as in the amount of grave-goods indicates that the grave is percieved as the home of the deceased, an interpretation which has certain support from literary sources. A change in religious form and meaning must be considered together with other social changes (Bennett 1987).

The external and internal grave-types on the island of Gotland often differ from the main patterns of Sweden. On Gotland con- 
temporaneous cemeteries often have different internal grave-types. Both the Sälle cemetery close to the settlement of Vallhagar and the Annelund cemetery at Visby were continiuously used from the Bronze Age into the Roman Iron Age, but they lack weapon-graves. The middle cemetery at Vallhagar has Pre-Roman weapon-graves and some of them show repeated burials. Extremely rich weapon-graves are known from other cemeteries. With these examples Erik Nylén warns against too hasty generalizations and application of too generally designed models in interpretation (Nylén 1987).

\section{VOTIVE DEPOSITS AND RELIGION}

Concerning the extensive category of votive deposits, Berta Stjernquist tries to find concepts that are operative in separating the religious/ritually caused deposits from the others. Important concepts are repeated actions, sacral meals and sacrifice of human beings (Stjernquist 1989).

From a religio-scientific point of view, Marianne Görman suggests that Celtic religion and symbolism may have been important in south Scandinavia from the Late Bronze Age and on. The sacrificial bog deposits from the Hjortspring find and others are interpreted by her as expressions of transferring Celtic sacrificial rite to Scandinavia. The first phase of erecting picture stones on Gotland might also be related to an originally Celtic religious sphere (Görman 1987, 1989).

Charlotte Fabech analyses the south Scandinavian votive deposits from the Roman Iron Age into the Migration Period. She is of the opinion that weapons, especially swords, were emphasized in the Migration Period deposits, which is important because swords were also symbols of power. The deposits also reflect war and warfare and the warrior as an ideal and exponent of a new social structure where the importance of lineages was diminishing. Fabech also emphasizes that votive offerings and ceremonies continue an ancient tradition. However, the Sösdala find is re-interpreted by her as a ritual grave deposition. In location, content and arrangement this find is very remindful of the Hunnish grave ritual performed in the uppermost social levels. Interpreted in this way, the Sösdala find may express contacts with a Hunnish aristocratic and martial life-style. The early runes as well as some characteristics of early art might also mirror religious/ideological innovation (Fabech 1989).

On the basis of a small excavation at the site of the earlier-known bog deposit at Finnestorp in Larv parish, Västergötland, Ulf Viking comments on old and new finds. Offerings were made from the fifth up to the seventh century, possibly during two separate phases. The deposits should be interpreted as offerings of war tributes but perhaps for different reasons, such as concurrence between lineages, between centres or, in a general way, as a ritual sign of power. It is important to observe that huge mounds were erected in the vicinity during the same centuries (Viking 1989).

A small, golden ring-cross has been found on the island of Orust in Bohuslän on the west coast. It has been dated to the fifthsixth centuries. Similar crosses have been found together with datable gold bracteates. The cross may indicate connections with Christianity. It is interesting that a small, golden, book-shaped pendant (a symbol of Holy Writ?) was buried with the treasure find at Hög Edsten in Kville parish, Bohuslän (Lamm, J.P. 1987).

Volumes 2 (1986) and 3 (1989) of Karl Hauck's extensive work Die Goldbrakteaten der Völkerwanderungszeit have been published and include contributions from several scholars. In several other works Hauck has treated the iconology of gold bracteates (e.g. Hauck 1986b). Among other topics he tries to reconstruct communication routes as well as the location of shel- 
tered sea-ports with the help of wreck-finds, place-names with a sacral meaning, and find-places for gold bracteates with divine motives (Hauck 1988).

Evert Baudou observes that the number of known graves in Norrland is relatively small, that their location indicates settlements, and that mounds were often erected on top of a house foundation that had burned down a short time before the mound was built. The Germanic word "Hof" had an original meaning as both "farm" and "mound" as well as "sanctuary". From this point of view the close connection among mound, selected individual and house might express the cult of ancestors (Baudou 1989).

\section{HANDICRAFT}

In a number of articles Kent Andersson has treated gold-foil beads and pendants with the aim of discerning groups that correspond to local workshops. The gold-foil beads from Öland in the Early Roman Iron Age indicate a local workshop because some of the beads are very much alike. The same trait cannot be seen on the Gotlandic ones (Andersson 1987). The gold-foil beads from different parts of Scandinavia show that individual workshops can be discerned also in some parts of Norway (Andersson 1990).

Laborative analyses of gold from Helgö and other sites show that both solidi and some ornaments have a high content of gold, though in general the gold content in the ornament is very varying (Oddy \& Meyer 1986).

Continuing her earlier works on Migration Period garnet jewellery, Birgit Arrhenius puts social aspects on the use of ornaments with insertions of garnets in the late Roman society and discusses why garnet jewellery exists in Scandinavia (Arrhenius 1988).

Glass fragments from goblets of the Snartemo type have been found at the settlement of Gårdlösa in Scania. Laborative analyses have shown interesting results. A review of the Swedish finds of these goblets is also published (Stjernquist 1986).

The iron slag from Building Group 3 at Helgö is evidently smithing slag. The dimensions of the activity were, however, restricted and aimed in the first hand at satisfying the needs of other workshops at the site. The currency bars derive from Norrland as well as from southern Sweden (Hallinder et al 1986).

\section{COINS}

Lennart Lind has treated Roman denarii found in Sweden, struck between 54 and 250 $\mathrm{AD}$. The similar composition of the treasure finds of denarii outside Limes indicates a common source for the denarii, an immense payment made about $240 \mathrm{AD}$ to peoples around the Wistula in order to obtain peace. The denarii were then brought to different regions, among them the islands of Öland and Gotland (Lind 1988).

A new investigation of late Roman Byzantine solidi on the Continent and in Scandinavia has been published by Ola Kyhlberg. He is of the opinion that the solidi have not imported continuously but during restricted periods of time with different datings according to region. The import must be viewed in a socio-economic context. The deposits reflect the passive extremity of the coins. Their original monetarian use was restricted during their later use, that is, they were not transformed according to monetarian principles (Kyhlberg 1986).

\section{DEBATE ON HELGÖ}

The discussions concerning the character and importance of Helgö proceed. In Thirteen Studies on Helgö different standpoints are represented, and those which concern the earlier phase of this settlement will be mentioned here. According to artefact chronology, the first settlement at Helgö can be dated to the fourth century. Handicraft and trade increased in importance up to the middle of the Vendel Period. In the Migra- 
tion Period Helgö became a regional centre for trade, and the settlement attracted craftsmen who worked perhaps seasonally. Judging from the kinds and number of finds, Helgö must not be seen as just an ordinary settlement with subsidiary means of livelihood (Lamm, K. 1988).

In the discussions about Helgö the importance of trade and handicraft has been strongly exaggerated. An analysis of the agrarian productivity and means of support concerning the from fiscal sources known farm of Bona, indicates that 2-3 farms could have survived fairly well on farming and cattle-breeding during the Iron Age (Carlsson, D. 1988).

At other settlements contemporaneous with Helgö, remains of handicraft are very common, as is exemplified by Gotlandic sites. If special importance is ascribed to the handicraft on Helgö, it is first necessary to decide what the "normal" level is (Carlsson, A. 1988b).

It is a paradox to state that the trade at Helgö flourished during the same time as the economy in large parts of Europe was founded on gifts and robbery. Helgö must be seen in its social-economic context. Hierarchic societies were probably established contemporaneous with Helgö, but in this context the concepts of "reciprocity" and "redistribution" should be used. Probably a surplus production was maintained at Helgö, and its products were distributed over vast distances. The handicraft at Helgö included products of high quality, and they can have been made by craftsmen dependent on a local leader or "prince", whose social position was maintained through gifts over vast distances - an interpretation well in accordance with both modern theory and circumstances known from the Continent (Christophersen 1988).

\section{A MIGRATION PERIOD CRISIS?}

On the recurrent topic "Migration Period crisis" many contributions have been made, hinted at in the above comments concerning changes in artefacts, graves and settlement patterns. As a general explanation of these changes Gerhard Flink supports Bo Gräslund's hypothesis that the Justinian plague also hit Sweden (Flink 1986). It has, however, not been proven from finds that the black rat, a prerequisite for dispersing the plague, lived in Scandinavia during the relevant time period (Näsman 1988).

Botanical analyses from settlement sites in middle Norrland have shown that barley, oats, rye as well as flax were grown during the Early Iron Age. In the fossil weed flora, manure-demanding species are very common, indicating that the fields were heavily manured. Concerning the managing of fields there was no crisis - they were not exhausted at all (Viklund 1989).

Dan Carlsson repeats his standpoint that the agrarian landscape of sixth-century Gotland was generally in accordance with that of the 17th century concerning the area of fields. Any extensive devastation of farms can not be traced (Carlsson, D. 1988a).

The interpretation "crisis" has been formulated against the background of experiences from regions with an abnormally high number of devastated farms. The concept of "crisis" is a product of too generalized models. The discussion must issue from regional circumstances as well as relations on above regional levels (Widgren 1988).

Changes are also evident in other periods than that discussed above. If farming systems and techniques were intensified during the Vendel Period, this seems very strange if the size of population diminished at that time. Stylistic changes, evident from artefacts, probably depend on strong, external influences. On the whole, the contacts with the Continent probably did not decrease, but the communication may have been centralised to an élite in an expanding structure of a new kind (Näsman 1988).

\section{English revised by Laura Wrang.}




\section{REFERENCES}

Andersson, K. 1987. Några exempel på verkstadstraditioner under äldre romersk tid. TOR Vol. 21, 1986-1987. Uppsala.

1989. En uppländsk källare från förromersk järnålder. TOR Vol. 22, 1988-1989. Uppsala.

- 1990. Berlocker och berlocktillverkare. Några nya infallsvinklar vid studiet av guldberlocker. MeddLUHM. NS 1989-1990. Lund.

Andersson, K. \& Hjärthner-Holdar, E. 1989. Tibble - en by utmed nya E18. Arkeologi $i$ Sverige 1986. Red. T. Andrae, A. Bennett, A. Broberg. Riksantikvarieämbetet och Statens historiska museer. Rapport RAÄ 1988 Stockholm.

Arrhenius, B. 1988. Bysantinska smycken från 300/400-talen funna i Norden Svenska kommittén för bysantinska studier. Bulletin 6 . Stockholm.

Arwill-Nordbladh, E. \& Jankavs, P. 1988. Valtersberg - liv och död för 2000 år sedan. FYND 1988/2. Göteborg.

Baudou, E. 1989. Hög - gård - helgedom i Mellannorrland under den äldre järnåldern. Arkeologi i norr 2. Red. E. Baudou. Umeå universitet. Institutionen för arkeologi.

Bennett, A. 1987. Graven - religiös och social symbol. Strukturer i folkvandringstidens gravskick i Mälarområdet. Theses and $\mathrm{Pa}$ pers in north-european archaeology 18. Institutionen för arkeologi, Stockholms universitet.

Beskow Sjöberg, M. 1987. Sammanfattande kommentarer och analys. Ölands järnåldersgravfält. Volym I. Alböke, Köpings, Räpplinge, Löts, Egby, Bredsätra och Gärdslösa socknar. Red. M. Beskow Sjöberg. Riksantikvarieämbetet och Statens historiska museer. Stockholm.

Carlsson, A. 1988. Helgö in the light of discoveries on Gotland. Thirteen studies on Helgö. The Museum of National Antiquities, Stockholm. Studies 7.

Carlsson, D. 1988a. Den folkvandringstida krisen. Folkevandringstiden $i$ Norden. En krisetid mellem aeldre og yngre jernalder. Red. U. Näsman \& J. Lund. Aarhus universitetsforlag. - 1988b. Helgö - central place or farmstead? Thirteen studies on Helgö. The Museum of National Antiquities, Stockholm. Studies 7.
Christophersen, A. 1988. Big Chiefs and Buddhas in the heart of the Swedish homeland. Thirteen studies on Helgö. The Museum of National Antiquities. Stockholm. Studies 7.

Fabech, Ch. 1989. Sydskandinaviske offerfund som kilde til jernalderens religion og ideologi. Arkeologioch religion. Rapport från arkeologidagarna 16-18 januari 1989. Red. L. Larsson \& B. Wyszomirska. University of Lund, Institute of Archaelogy. Report Series No 34.

Fernholm, G. 1987. Bronsålders- och järnåldersboplatser i Östergötland. UV-s undersökningar under åren 1967-1884. 7000 år på 20 år. Arkeologiska undersökningar i Mellansverige. Riksantikvarieämbetet. Stockholm.

Flink, G. 1986. Ölands stensträngsområden och den justinianska pesten. Bebyggelsehistorisk Tidskrift 11. Fornlämningar och bebyggelsehistoria. Ed. K.G.Selinge. Stockholm.

Gerdin, A.-L. 1989. Bål i glas och glas i bål - bägare i järnåldersgravar. Gotländskt arkiv 61. Visby.

Görman, M. 1987. Nordiskt och keltiskt. Sydskandinavisk religion under yngre bronsålder och keltisk järnålder: Diss. Lund.

- 1989. Hur kan man använda arkeologiskt material i religionshistorisk forskning? Några metodiska överväganden och försök. Arkeologi och religion. Rapport från arkeologidagarna $16-18$ januari 1989. Red. L. Larsson \& B. Wyszomirska. University of Lund. Institute of Archaeology. Report Series No 34.

Göthberg, H. 1989. Järnålderns hus i sydvästra Uppland. TOR Vol. 22, 1988-1989. Uppsala.

Hallinder, P., Flyge, H. \& Randrup, J. 1986 . The Iron Slag from Helgö - An Archaeological and Scientific Study. Excavations at Helgö X. Ed. A. Lundström \& H. Clarke. KVHAA. Stockholm.

Hauck, K. (Ed). 1986a. Die Goldbrakteaten der Völkerwanderungszeit. Contributions by $\mathrm{M}$. Axböe, K. Düwel, L.v Padberg, C. Wypior. Vol. 2. 1: Ikonographischer Katalog 2. Text. München.

- 1986b. Die Wiedergabe von Göttersymbolen und Sinnzeichen der A-, B- und C-Brakteaten auf D-und F-Brakteaten, exemplarisch erhellt mit Speer und Kreutz. Zur Ikonologie der Goldbrakteaten, XXXV. Frühmittelalterliche 
Studien. 20.

- 1988. Völkerwanderungszeitlicher Seeverkehr, erhellt mit Schiffsresten und Fundorten von Goldbrakteaten. Zur Ikonologie der Goldbrakteaten XXXIX. Trade and Exchange in Prehistory. Studies in honour of Berta Stjernquist. Ed. B. Hårdh, L. Larsson, D. Olausson \& R. Petré. Acta Archaeologica Lundensia. Series in $8^{\circ}$. No 16 . Lund.

- (Ed). 1989. Die Goldbrakteaten der Völkerwanderungszeit. Contributions by $\mathrm{M}$. Axböe, K. Düwel, K. Hauck, L. v Padberg, H. Rulffs. Vol. 3. 1: Ikonographischer Katalog 3. Text. 2: Ikonographischer Katalog 3. Tafeln. München.

Hedman, A. 1987. Östra Mellansveriges järnåldersboplatser. 7000 år på 20 år. Arkeologiska undersökningar i Mellansverige, Riksantikvarieämbetet. Stockholm.

Herschend, F. 1988. Bebyggelse och folkvandringstid på Öland. Folkevandringstiden i Norden. En krisetid mellem aeldre og yngre jernalder. Ed. U. Näsman \& J. Lund, Aarhus universitetsforlag.

Hjärthner-Holdar, E. \& Söderberg, S. 1987, Brons- och järnåldersbebyggelse i Uppland. 7000 år på 20 år. Arkeologiska undersökningar i Mellansverige, Riksantikvarieämbetet, Stockholm.

Klang, L. 1986. Kolonisation och bebyggelseutveckling i nordöstra Smålands inland. Bebyggelsehistorisk Tidskrift 11. Fornlämningaroch bebyggelse. Ed. K.G. Selinge. Stockholm.

Kyhlberg, O. 1986. Late Roman and Byzantine Solidi. An archaeological analysis of coins and hoards. Excavations at Helgö X. Ed. A. Lundström \& H. Clarke. KVHAA Stockholm.

Lamm, J. P. 1987. Ett folkvandringstida ringkors från Röra i Stala på Orust. Bohuslän. Årsbok 1987. Uddevalla.

Lamm, K. 1988. Helgö - international trading centre, local market or farming community? Thirteen studies on Helgö. The Museum of National Antiquities. Stockholm. Studies 7.

Larsson, T. B. 1989. A spatial approach to socioeconomic change in southern Sweden 500 B.C. - A.D. 500. Approaches to Swedish Prehistory. Eds. T. B. Larsson \& H. Lundmark. BAR International Series 500. Oxford.

Liedgren, L. 1987. Synpunkter på den sedentära bebyggelsens etablering i Norrland. Bebyggelsehistorisk Tidskrift 14. Samer och germa- ner i det förhistoriska Norrland. Red. P. Ramqvist. Stockholm.

- 1989. Bebyggelseutvecklingen i Forsa, Hälsingland, under den äldre järnåldern. Arkeologi $i$ norr 2. Ed. E. Baudou. Institutionen för arkeologi. Umeå universitet.

Lind, L. 1988. Romerska denarer funna i Sverige. Text. Diss. Stockholm.

Lundh, G. 1988. Västra Änghagen-huset. FYND 1988/2. Göteborg.

Lundmark, H. 1989. The Growth of Hierarchies in Low-Centralized Societies: Some Archaeological Problems. Approaches to Swedish Prehistory. Eds. T. B. Larsson \& H. Lundmark. BAR International Series 500. Oxford.

Magnusson, G. 1987. Järn, kolonisation och landskapsutnyttjande i Norrlands inland. Bebyggelsehistorisk Tidskrift 14. Samer och germaner i det förhistoriska Norrland. Ed. P. Ramqvist. Stockholm.

Melander, J. 1989. Analys av lerklining från ett järnåldershus i Hälsingland. Arkeologi $i$ norr 2. Red. E. Baudou. Umeå universitet. Institutitionen för arkeologi.

Nylén, E. 1987. Komplex social skiktning och modellbyggandets faror. TOR Vol.21. 19861987. Uppsala.

Näsman, U. 1988. Den folkvandringstida ? krisen i Sydskandinavien. Folkevandringstiden $i$ Norden. En krisetid mellem aeldre og yngre jernalder. Eds. U. Näsman \& J. Lund. Aarhus universitetsforlag.

Oddy, W. A. \& V. E. G. Meyer, 1986. The Analysis of Gold Finds from Helgö and their Relationships to other Early Medieval Gold. Excavations at Helgö X. Eds. A. Lundström \& H. Clarke. KVHAA. Stockholm.

Olausson, M. 1987. Hillforts, subsistence and economic centralization A.D. 300-500 in eastern middle Sweden. Theorethical approaches to artefacts, settlement and society. Studies in honour of Mats P. Malmer: Eds. G. Burenhult, A. Carlsson, Å. Hyenstrand \& T. Sjøvold. BAR International Series 366 (ii). Oxford.

Ramqvist, P. 1987. Mellannorrland under äldre järnålder. Några aspekter på samhällsstrukturen. Bebyggelsehistorisk Tidskrift 14. Samer och germaner i det förhistoriska Norrland. Red. P. Ramqvist. Stockholm.

Stjernquist, B. 1986. Glass from the settlement of Gårdlösa, Southern Sweden. MeddLUHM, NS 6, 1985-1986. Lund. 
- 1989. Arkeologiskt material som belägg för religion. Tolkningen som problem. Arkeologi och Religion. Rapport från arkeologidagarna 1618 januari 1989. Red. L. Larsson \& B. Wyszomirska. University of Lund. Institute of Archaeology. Report Series No 34.

Tagesson, G. 1990. En nyupptäckt fornborg i Vist socken. Östergötland 1990.

Ulfhielm, A. 1988. Dragby - social struktur och organisation under förromersk järnålder. Stockholm Archaeological Reports 21. Institutionen för arkeologi. Stockholms universitet.

Viking, U. 1989. Finnestorpfyndet - ett mossfynd från centrala Västergötland. Västergötlands fornminnesförenings tidskrift 1987-1988.

Viklund, K. 1989. Jordbrukskris i Norrland i slutet av den äldre järnåldern? Arkeologi i norr 2. Red. E. Baudou. Umeå universitet. Institutio- nen för arkeologi.

Widgren, M. 1988. Om skillnader och likheter mellan regioner. Folkevandringstiden $i$ Norden. En krisetid mellem aeldre og yngre jernalder. Eds. U. Näsman \& J. Lund. Aarhus universitetsforlag.

Wigren, S. 1987. Bronsålderns och den äldsta järnålderns boplatser i Södermanland. 7000 år på 20 år. Arkeologiska undersökningar i Mellansverige. Riksantikvarieämbetet. Stockholm.

Winberg, B. 1986. Stensträngar och gravar som källmaterial vid studiet av järnålderns bebyggelse. Bebyggelsehistorisk tidskrift 11. Fornlämningar och bebyggelsehistoria. Red. K.G. Selinge. Stockholm.

Ängeby, G. 1989. Klippöverhänget på Järnklätt ett förhistoriskt jaktpass. Bohuslän. Årsbok 11. Uddevalla. 